\title{
Communication \\ Thai Orchid Genetic Resources and Their Improvement
}

\author{
Kanchit Thammasiri \\ Department of Plant Science, Faculty of Science, Mahidol University, Rama VI Road, Phayathai, Bangkok 10400, \\ Thailand; kanchitthammasiri@gmail.com; Tel.: +66-891-327-015; Fax: +66-235-471-72 \\ Academic Editor: Douglas D. Archbold \\ Received: 1 December 2015; Accepted: 8 July 2016; Published: 28 July 2016
}

\begin{abstract}
Thailand is the origin of about 1300 species and 180-190 genera of orchids, comprising the major tropical orchids in the world. These wild Thai orchids grow naturally in various habitats and have unique flowers, stems, leaves, and roots. Many genera, including Vanda, Rhynchostylis, Ascocentrum, Aerides, Phalaenopsis, Doritis, Dendrobium, Bulbophyllum, Cirrhopetalum, Spathoglottis, and Paphiopedilum, contribute significantly to the Thai orchid industry for cut-flowers and potted plants. The improvement of these orchids' horticultural characteristics has been significant through breeding, tissue culture, and cultural practices, as well as by technological applications and extension. Orchids will continue to dominate other ornamental crops in Thailand due to their diversity, better technologies, know-how from research, suitable climatic conditions, and experienced and skillful growers and exporters, as well as their nationwide popularity.
\end{abstract}

Keywords: Thai orchid species; orchid diversity; breeding

\section{Introduction}

Thailand is the origin of about 1300 species and 180-190 genera of orchids, comprising the major tropical orchids in the world. Although Thailand is a natural habitat for several diverse species of orchids, interest in growing cultivars for their economic value was first recorded in 1913 with the introduction of some exotic materials by a foreigner working in Thailand. Having a hobby of growing orchids, he brought cattleyas and some other genera to Bangkok, all of which were subsequently sold to a high ranking officer. Several other high rank and file individuals in the country also became interested in orchid growing as a hobby during the same period. Information concerning orchid growing, an expensive hobby suitable only for the rich and elite, was provided by a small group of high-ranking officials and older, wealthy people in Thailand.

Orchids have the highest value among several tropical ornamental crops, especially among cut-flower crops which are important to Thai agriculture and the economy. Although orchid growing started as a hobby about 100 years ago, until 1966 only a small amount of orchid cut-flowers were exported from Thailand to Europe. The introduction of the Dendrobium cultivar "Pompadour" proved to be a landmark that also increased the popularity for orchid cultivation in Thailand. This hybrid was easy to grow and propagate by division, and was high yielding with a long vase-life. Thailand attained the status of the world's leading producer and exporter of orchids in a little over a decade, and it has held the top rank since 1979.

Orchid cultivation in Thailand has been confined to the Central Plain, mainly in Bangkok and its nearby provinces, where there are favorable climatic conditions, water, transportation and a marketing system. Orchid production takes place mainly in three provinces, Samut Sakhon, Bangkok, and Nakhon Pathom, followed by the nearby central provinces and those to the north and the south of Thailand. The estimated total area for orchid cultivation in 2012 was 3003 ha. The suitable environment, high orchid genetic diversity, efficient infrastructure, experienced growers, technological applications, 
extension, training, teaching, and research, as well as business skills, have each contributed to the success of orchid production and trade in Thailand [1]. Many farmers have made orchid cultivation their main occupation, often with higher returns than other crops. Commercial orchid production has been facilitated by over 10 tissue culture laboratories. Marketing has been facilitated for growers by over 50 export organizations engaged exclusively in export of Thai orchids [2].

Thailand has a long history of orchid trade, especially for export. It is estimated that $54 \%$ of the orchids produced in Thailand are currently exported, while the remaining $46 \%$ are consumed in the domestic markets. Exports of orchid cut-flowers began in 1963 with a few hundred thousand sprays of mostly "Pompadour" sent to European markets. The export value of orchid cut-flowers has increased sharply to about 60 million U.S. \$ in 2014. The export of orchid cut-flowers still predominates, but the export of orchid plants has also rapidly increased to about 22 million U.S. \$ in 2014 (Figure 1) [2].

The imports of ornamental plants and flowers into Thailand, especially orchid plants and cut-flowers, has been relatively low because there are a large variety of indigenous tropical orchids which are relatively inexpensive and good quality.

The success of Thai orchid cultivation and trade of cut-flowers and potted plants was a result of concerted national efforts with respect to germplasm resource management, research, training, extension, technological applications, and communication networks $[3,4]$.

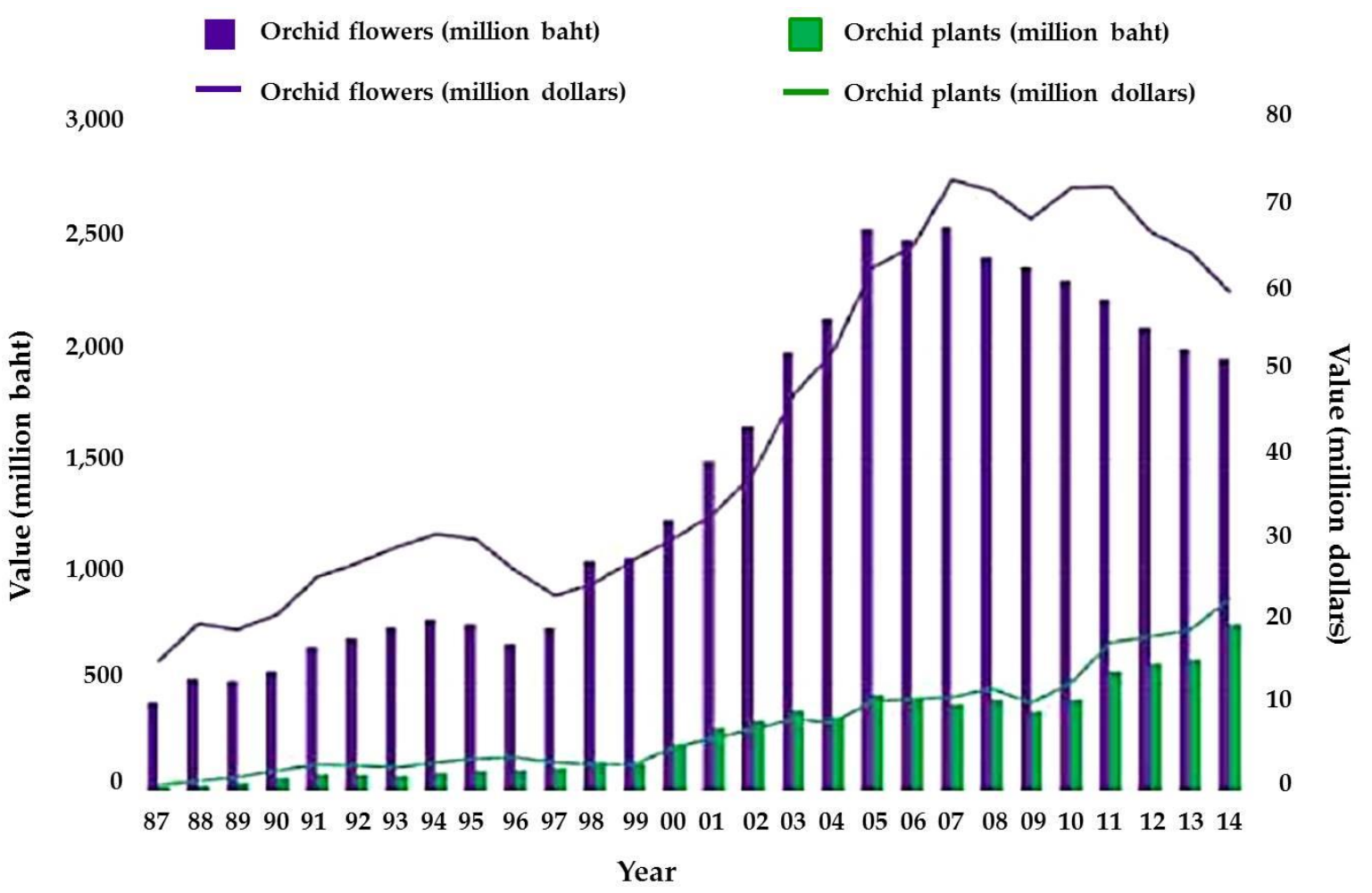

Figure 1. Orchid flower and plant export value from Thailand during 1987-2014.

\section{Thai Orchid Genetic Resources}

Orchidaceae (Orchid family) is subdivided into six subfamilies [5], with Thailand as the origin of all six subfamilies. They have distinguishing characteristics described briefly [6] as follows:

1. APOSTASIOIDEAE: This subfamily is sometimes separated into a new family, named Apostasiaceae by some authors as it is quite different in size and shape of sepals and petals with two or three fertile stamen and an ovary with three locules. In Thailand, it is represented by two genera and five species, and is mainly confined to moist evergreen lowland forests. 
2. CYPRIPEDIOIDEAE: The well-known slipper orchids belong to this subfamily. Their common characteristic feature is a deeply saccate or slipper-shaped lip. The unusual structure includes a column with two lateral stamen, a large shield-like median staminode, and lateral sepals connate along the inner margin forming one sepal mostly hidden behind the lip. The genus Paphiopedilum is only found in Thailand with about 14 species.

3. NEOTTIOIDEAE: This orchid group is mainly terrestrial in moist evergreen forests with more or less fleshy rhizomes or tubers. There are about 24 genera and 68 species in Thailand.

4. ORCHIDOIDEAE: This subfamily is very close to the subfamily Neottioideae in general habit, as well as in habitat, but differs in having tubers or root-stem tuberoids, an anther usually basally attached to the viscidium (or visidia), and with the apex of the rostellum often protruding between the thecae. There are about 10 genera and 65 species recorded in Thailand. Habenaria is the most well-known one.

5. EPIDENDROIDEAE: This is the largest subfamily, growing in various habitats. Their soft, waxy pollinia, normally without stipe and viscidium, is very characteristic of this group. There are about 63 genera and 692 species found in Thailand. Many of them are very attractive in floral size, color and longevity. Thus, they are very popular among orchid growers.

6. VANDOIDEAE: This subfamily is very close to the Epidendroideae and has recently been included in the latter subfamily. The difference is mainly in the hard or cartilaginous pollinia which usually has a stipe and viscidium. There are about 78 genera and 289 species in Thailand. Many of them are also very popular, as are those in the Epidendroideae.

\section{Cultivated Thai Orchid Genera and Their Improvement}

Among 180-190 genera and 1300 species of wild Thai orchids, about 11 genera are cultivated as a hobby and for commercial purposes. In addition, they have been improved through breeding and production technologies. The details of these genera are as follows:

\subsection{Vanda}

The genus Vanda is an epiphyte and monopodial orchid with large stems. There are about 40-50 species in this genus. They grow in tropical Asia from East India to Southeast Asia, Indochina, New Guinea, Australia, Solomon Islands, the Philippines, Taiwan and nearby islands. In Thailand, 9 species are found. They are popular for growing, and are used as parents, especially Vanda coerulea (Figure 2) because they give large flowers, and a long spray with a good arrangement of flowers. Flower colors of the hybrids are blue to red-purple (Figure 3). Vanda can be crossed with other monopodial genera, such as Rhynchostylis, Aerides, Ascocentrum, etc., and produce many outstanding cultivars for cut-flowers and potted plants. 

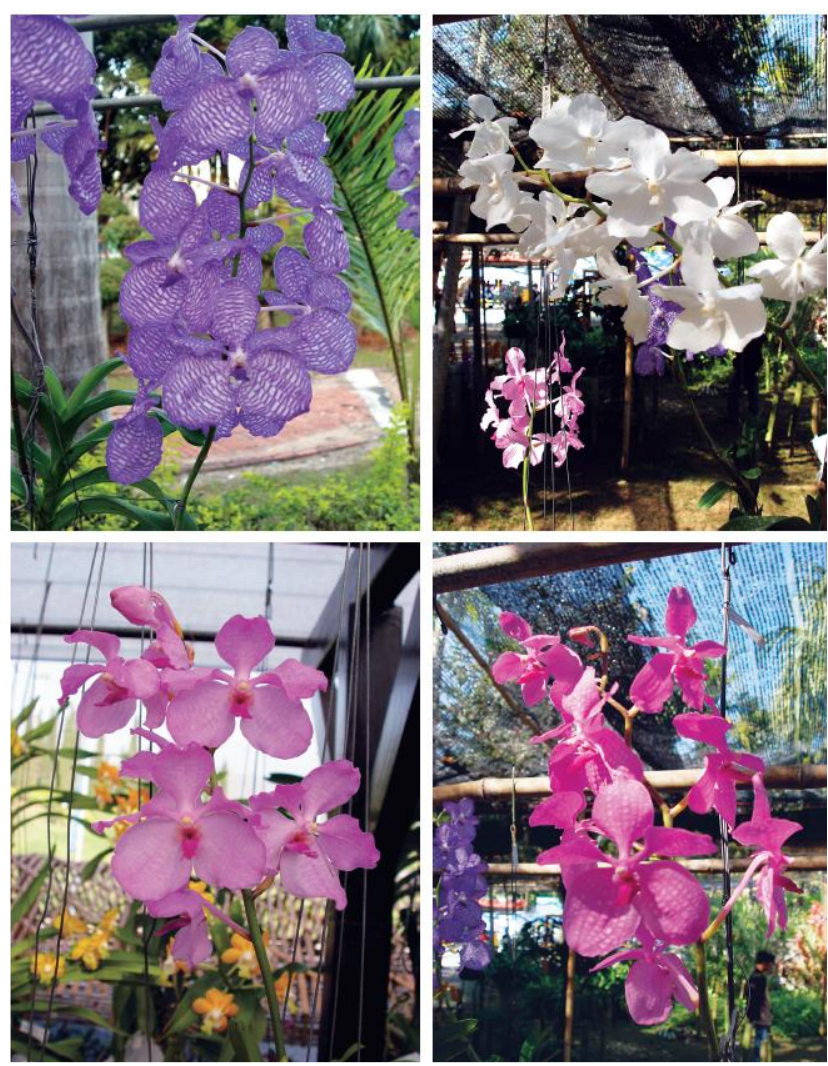

Figure 2. Variation in flower colors of Vanda coerulea.

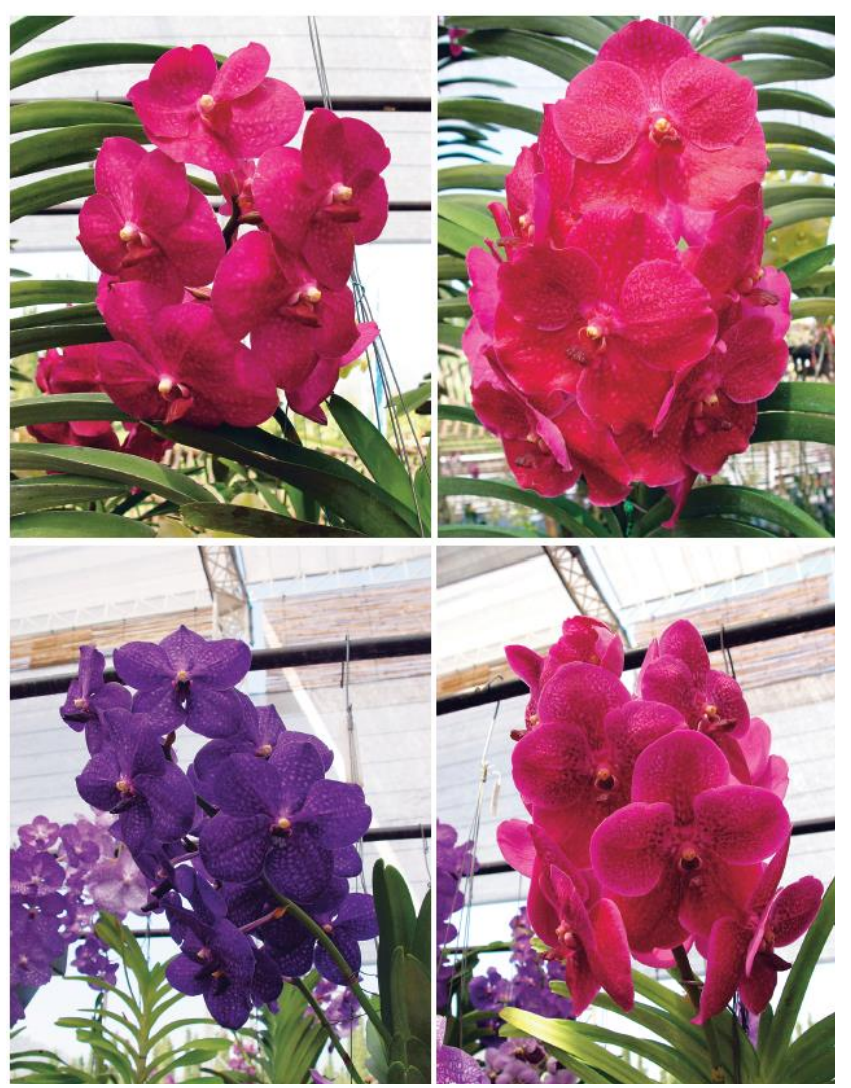

Figure 3. Vanda hybrids. 


\subsection{Rhynchostylis}

This genus is epiphytic, monopodial, and has medium to large stems with thick leaves. In Thailand, there are 3 species in this genus, namely R. gigantea (Figure 4), R. retusa (Figure 5) and R. coelestis (Figure 6). The flower colors of Rhynchostylis gigantea are white, white with red-purple spots, red-purple and orange. This genus is popularly grown as potted plants and as parents for producing interspecific hybrids (Figures 7 and 8).
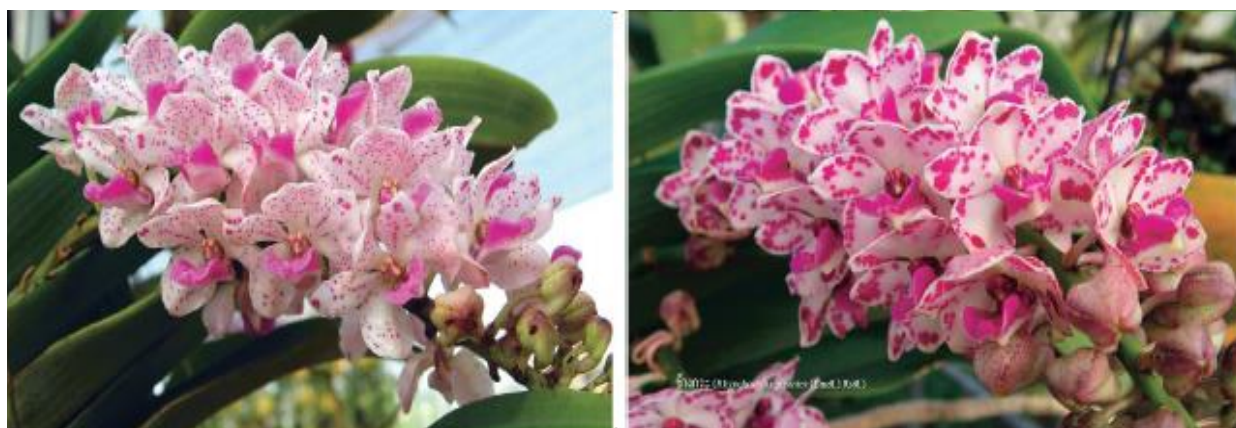

Figure 4. Rhynchostylis gigantea.

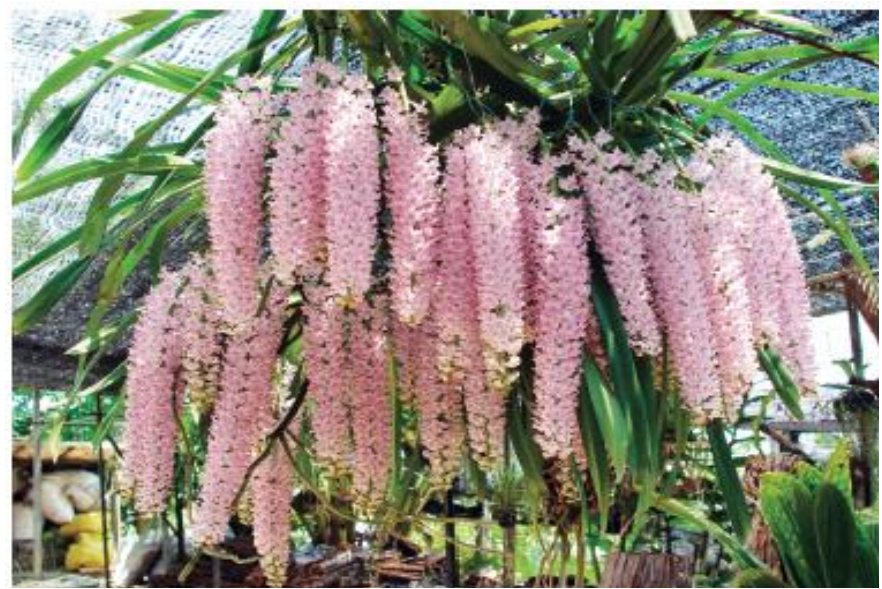

Figure 5. Rhynchostylis retusa.

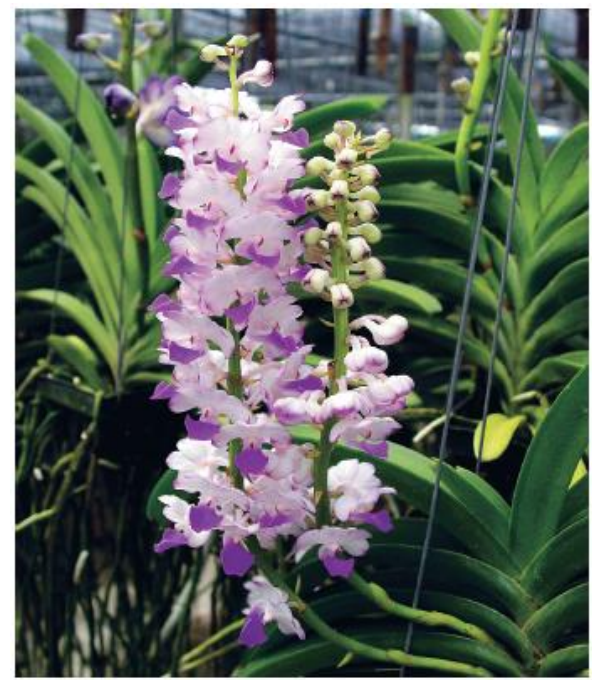

Figure 6. Rhynchostylis coelestis. 


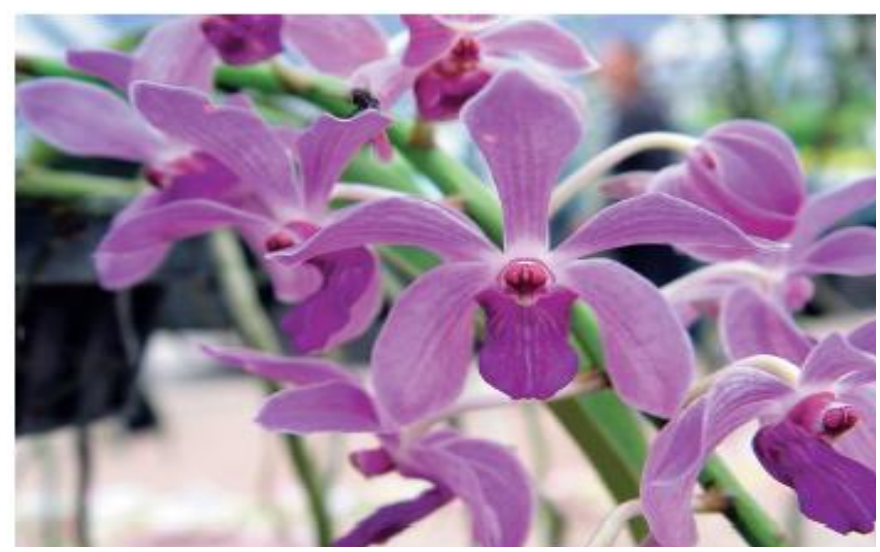

Figure 7. A hybrid of Rhynchostylis gagantea and Vanda coerulea.

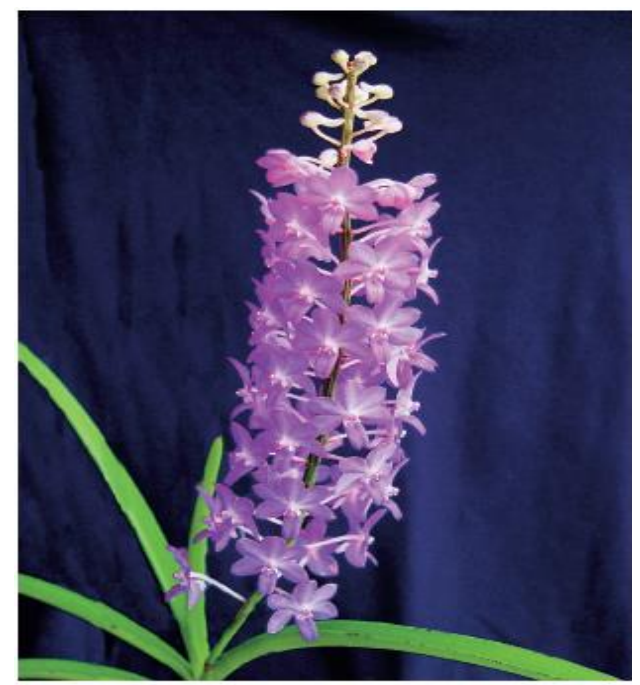

Figure 8. A hybrid of Rhynchostylis coelestis and Seidenfadenia mitrata.

\subsection{Ascocentrum}

This genus is a small epiphyte and monopodial orchid with 3 types of flower color, purple-red (A. ampullaceum), red (A. curvifolium), and orange (A. miniatum) (Figure 9).

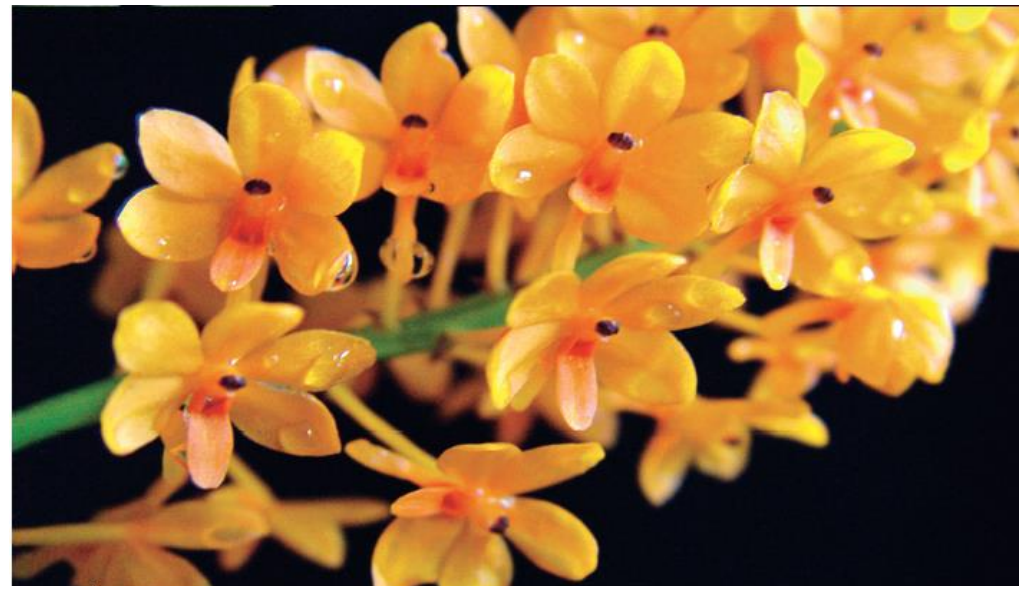

Figure 9. Ascocentrum miniatum. 


\subsection{Aerides}

This genus (Figure 10) is a small epiphyte and monopodial orchid and can grow in strong sunlight. It has beautiful flowers and sprays, so it is popular for hobbyists to grow and use for orchid improvement.

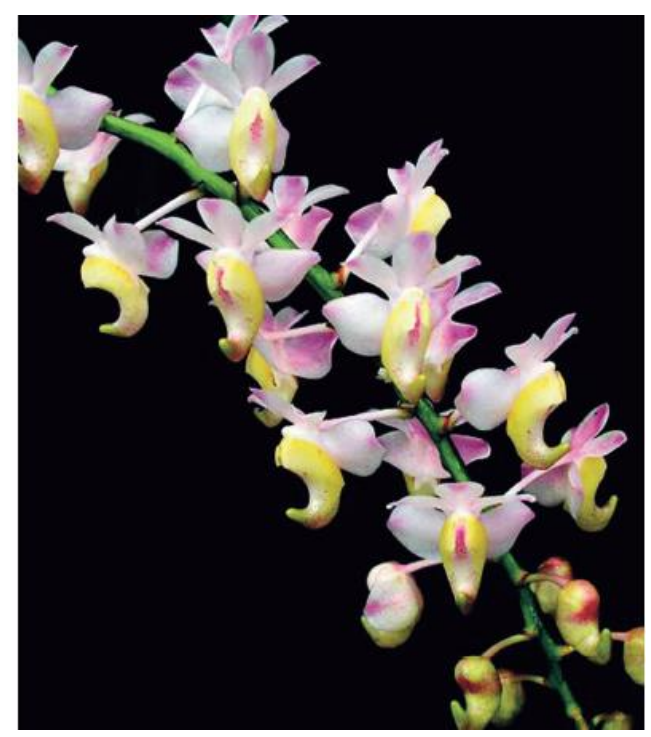

Figure 10. Aerides odorata.

\subsection{Phalaenopsis}

This genus (Figure 11) is a short epiphyte and monopodial orchid with long leaves. It has one to many flowers per spray, and some continuously bloom one at a time. This genus, especially for its hybrids (Figure 12), is economically important in Taiwan.

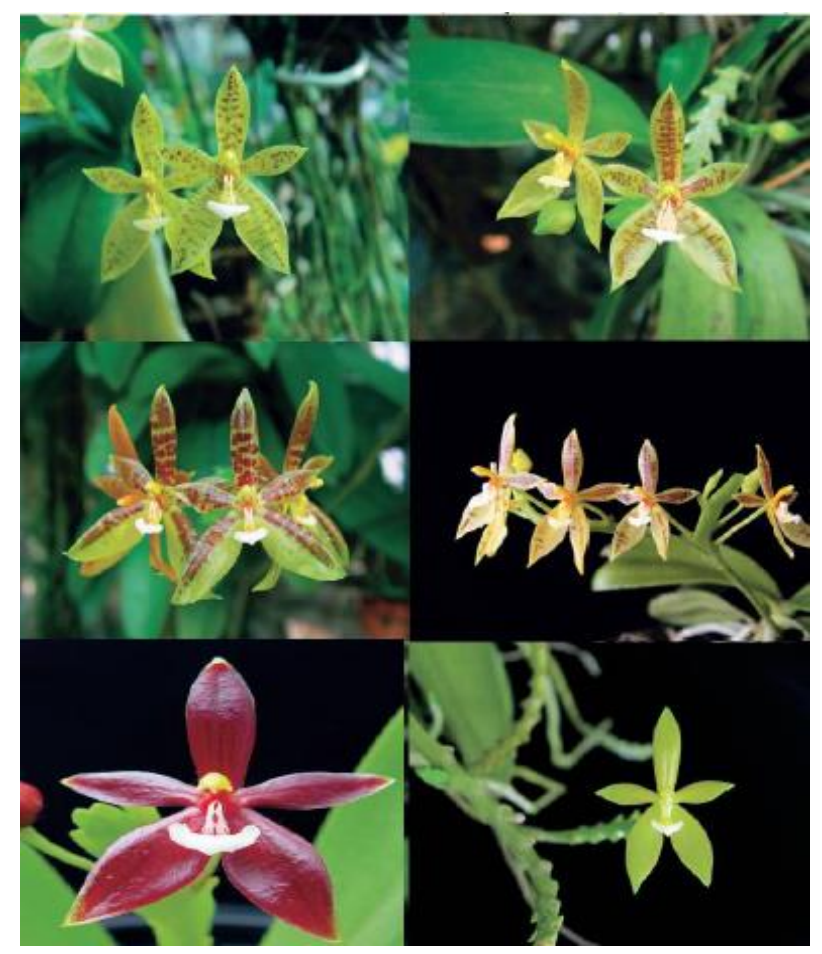

Figure 11. Variation in flower color of Phalaenopsis cornu-cervi. 

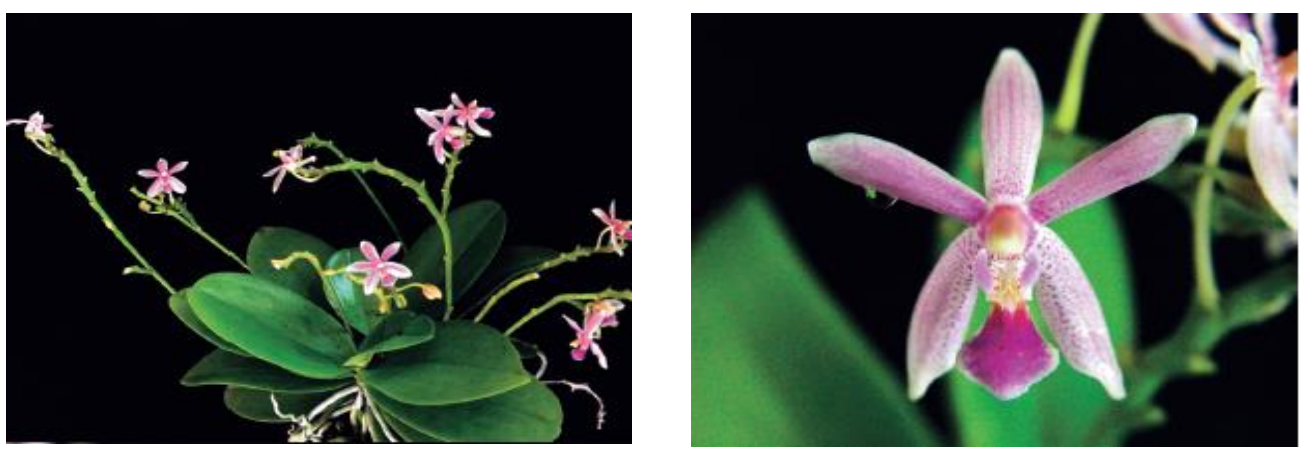

Figure 12. Phalaenopsis hybrids.

\subsection{Doritis}

This genus (Figure 13) is terrestrial and can grow in sand or rock. Its sprays are straight and hard with 5-15 flowers which continuously bloom for 5-6 months. It grows easily as a potted plant and has been crossed with Phalaenopsis to get a medium-sized straight flower spray (Figure 14).
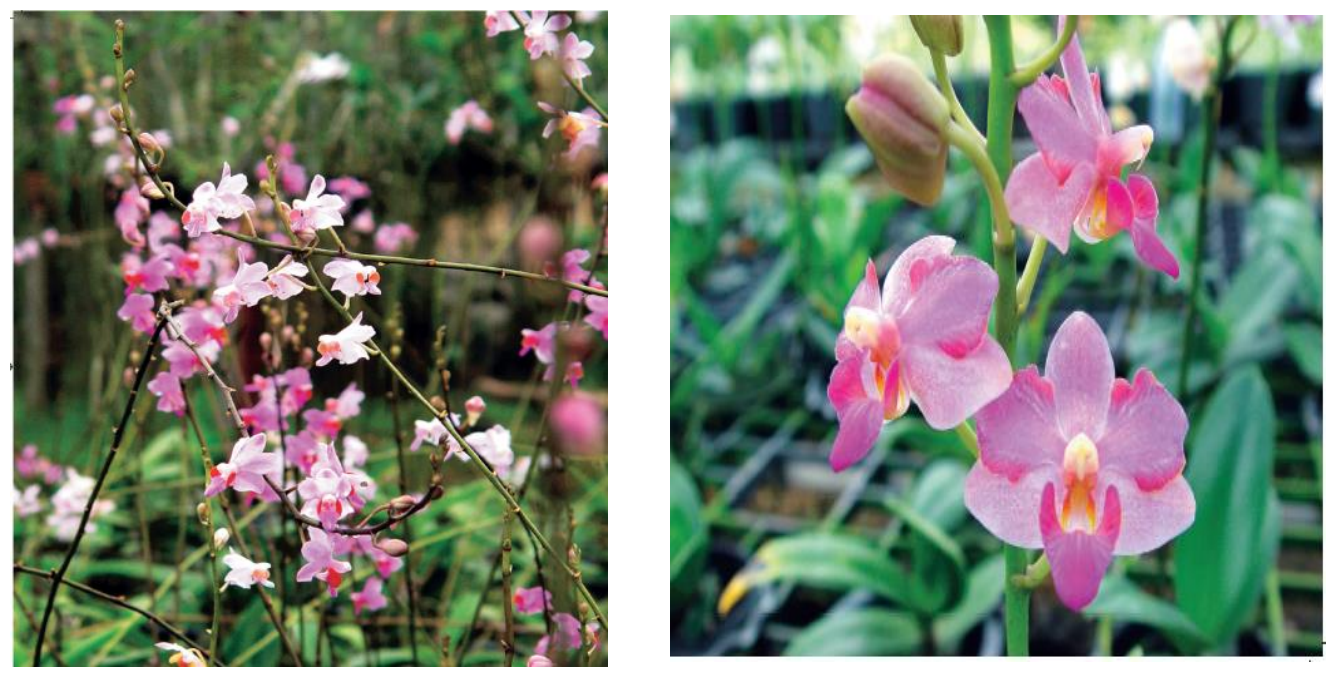

Figure 13. Doritis pulcherrima.
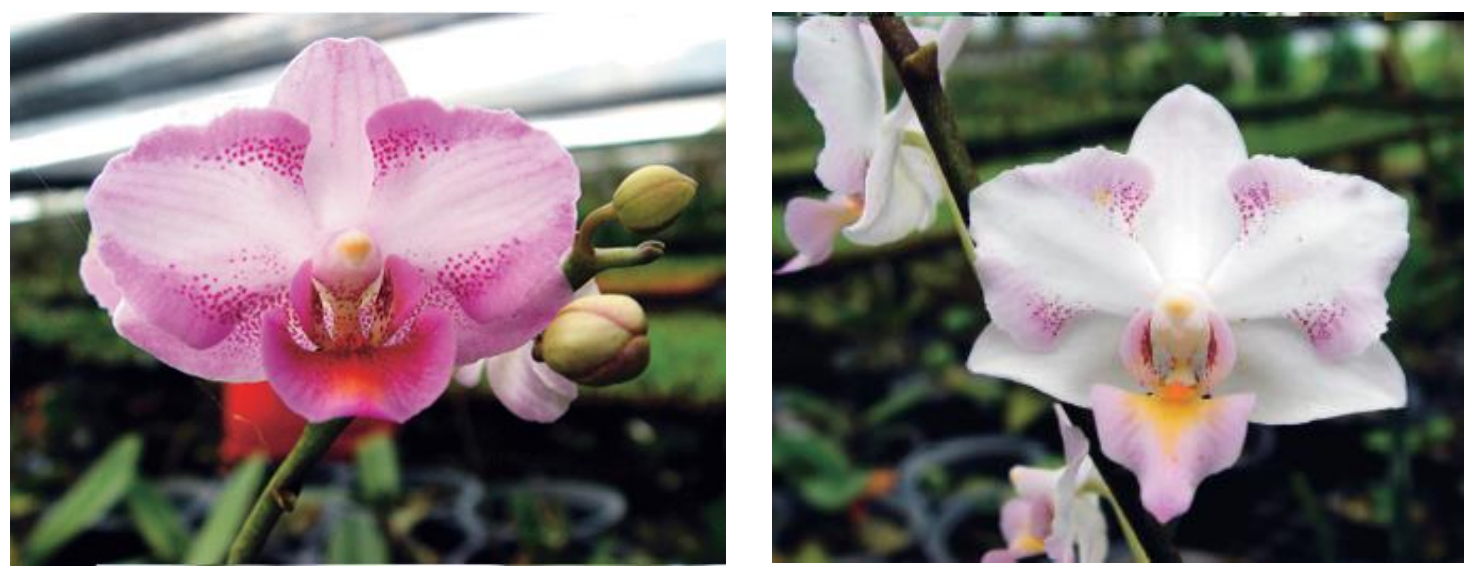

Figure 14. Doritis hybrids. 


\subsection{Dendrobium}

This genus (Figure 15) is a sympodial orchid with diversity in size and shape of stems, leaves, its habitats and growth habits. They are over 1000 species in the genus around the world. They are popularly grown and used in breeding to get outstanding hybrids (Figure 16).

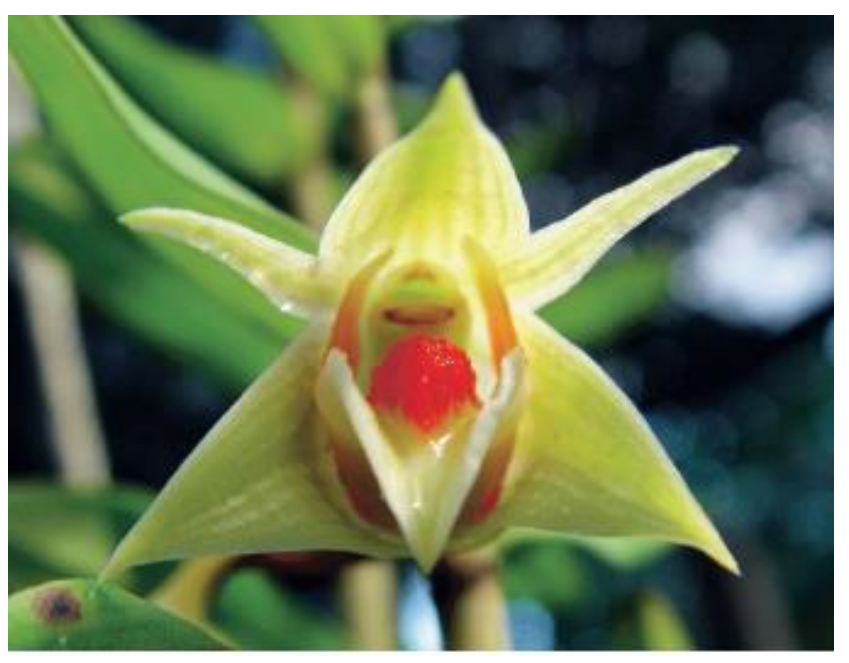

Figure 15. Dendrobium cruentum.

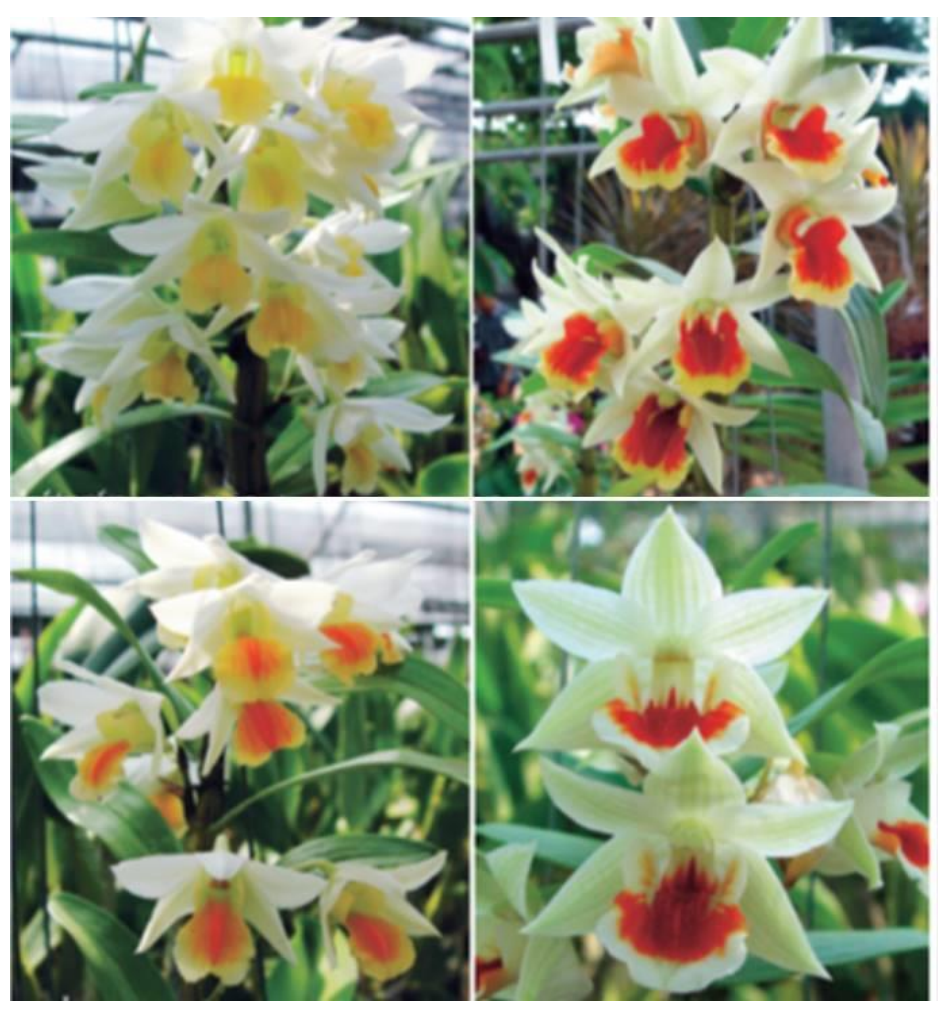

Figure 16. Dendrobium cruentum hybrids.

\subsection{Bulbophyllum}

This genus (Figure 17) is a small sympodial orchid. Pseudobulbs always have angles with thick leaves. They are easy to propagate by division with only one pseudobulb and are popular for growing as potted plants. 


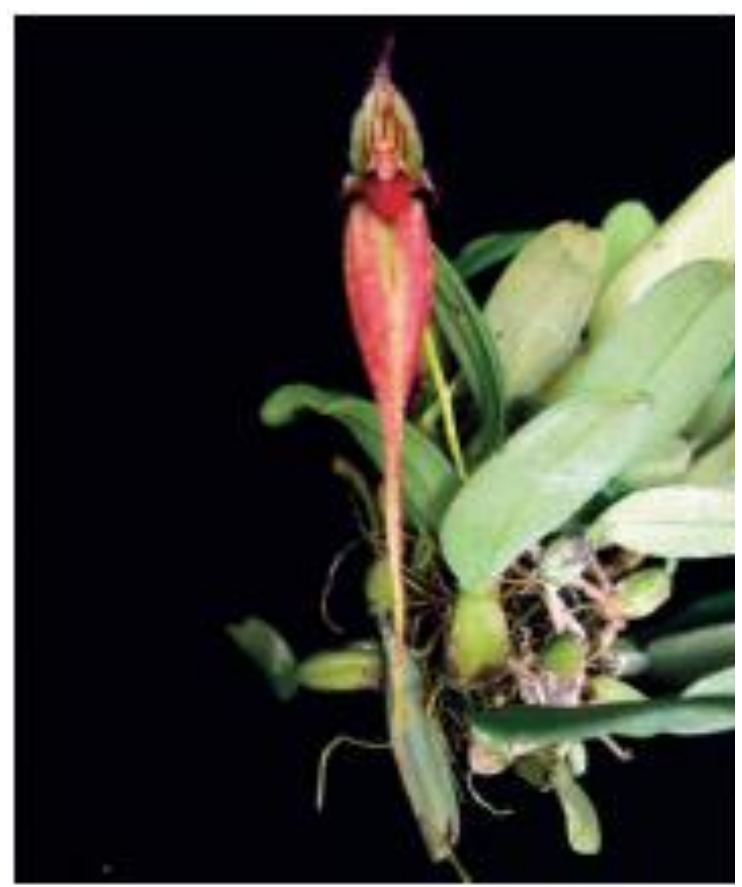

Figure 17. Bulbophyllum putidum.

\subsection{Cirrhopetalum}

This genus (Figure 18) was separated from Bulbophyllum because its dorsal sepal is smaller than the lateral sepals. The flower spray is umbellate and the pseudobulb is cone shaped.

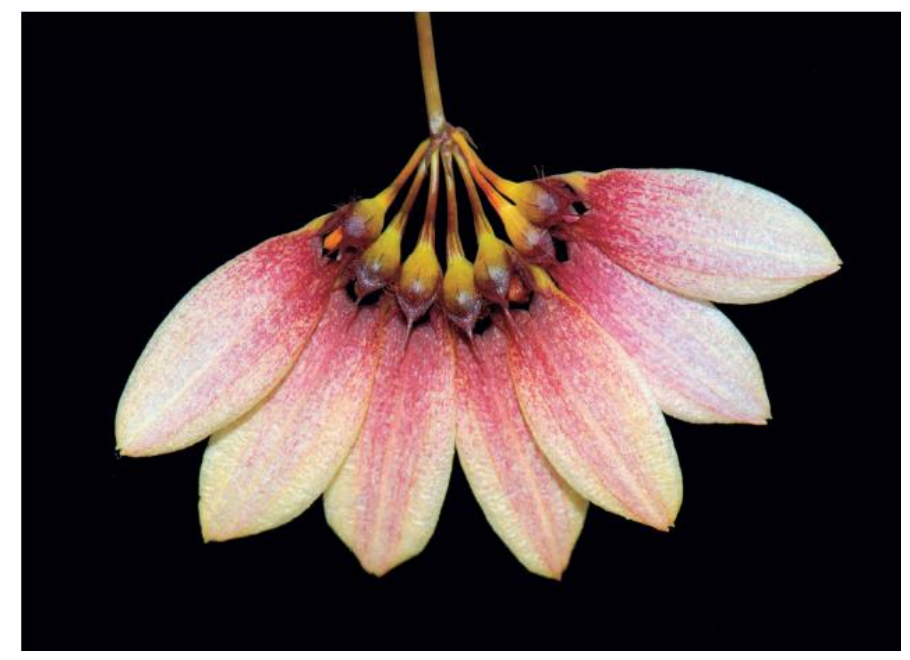

Figure 18. Cirrhopetalum lepidum.

\subsection{Spathoglottis}

This genus (Figure 19) is a terrestrial orchid with a pseudobulb and rhizome. They are used for landscaping since they can grow well in the soil. In Thailand, there are 5 species. Spathoglottis plicata is used to make hybrids (Figure 20) with many colorful orchids. 


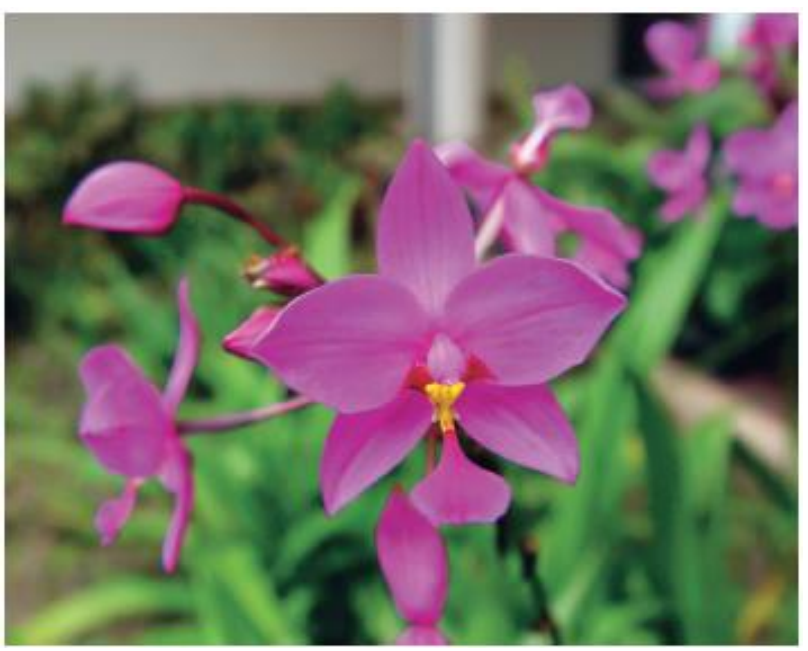

Figure 19. Spathoglottis plicata.

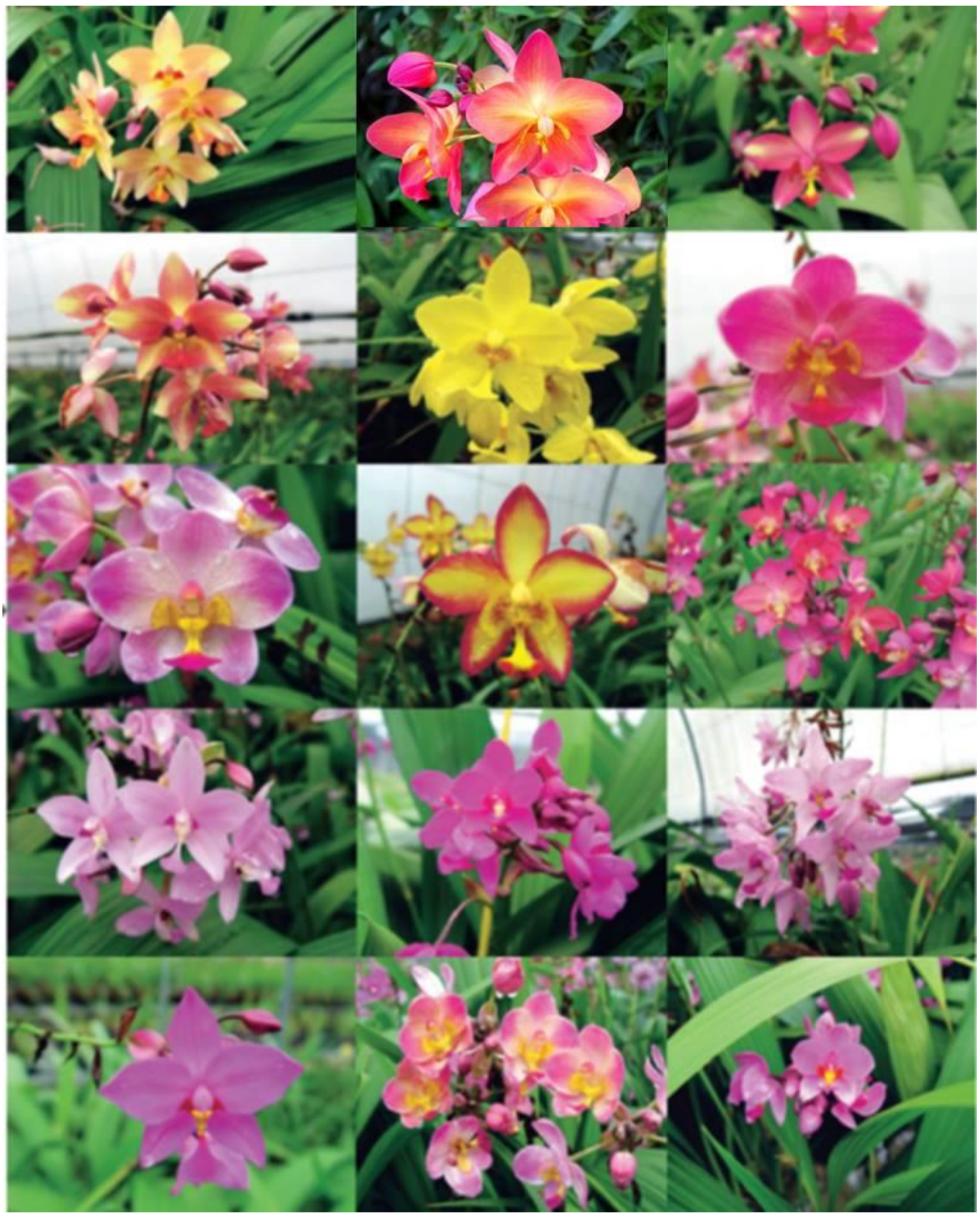

Figure 20. Spathoglottis hybrids. 


\subsection{Paphiopedilum}

This genus is called "Lady's slipper" because the lip looks like lady's shoes. There are 15 species reported in Thailand. They are popular to grow from seeds as potted plants. The popular species used for trade are P. bellatulum (Figure 21a), P. concolor, P. exul (Figure 21b). P. godefroyae, P. niveum, P. callosum, P. parishi and P. hirsutissimum.

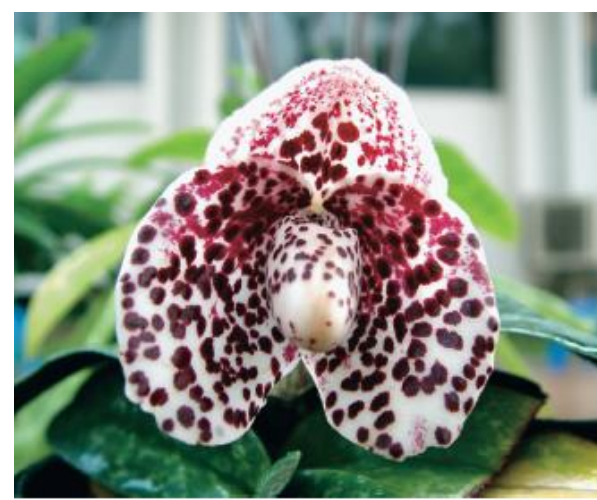

(a)

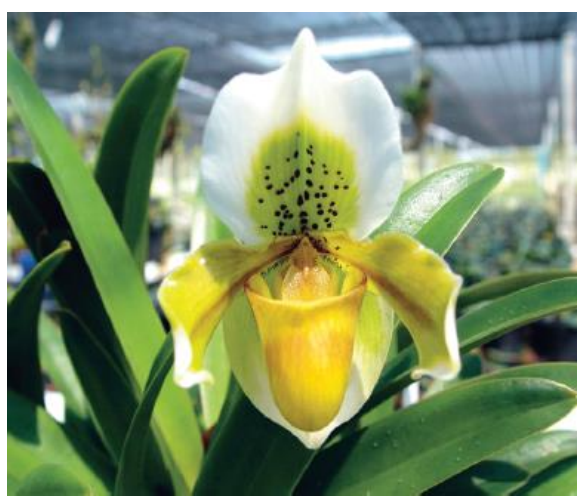

(b)

Figure 21. Paphiopedilum bellatulum (a) and Paphiopedulum exul (b).

In addition to the breeding of cultivated Thai orchid genera, Thai orchidists from both the public and private sectors have improved the orchid production technologies for sustainable use, modifying greenhouses, water resources, planting material and containers, pest control, plant breeding, tissue culture [7] and postharvest management. These improvements have resulted in increased yield and quality and have thereby directly enhanced production and increased quantity of orchids for export [8].

\section{Conclusions}

Thai orchid production has a bright future where export values are expected to remain high and stable. Orchids will continue to dominate other ornamental crops in Thailand due to high orchid diversity, better technological know-how, suitable climatic conditions, and experienced and skillful growers and exporters, as well as their popularity with the public.

The success story of orchids in Thailand is a good example of the development of an ornamental crop through its diversity in natural habitats to become a major crop. The development of the Thai orchid industry has taken a long time to develop, but it is now a high-income business and an important part of the national economy.

Conflicts of Interest: The author declares no conflict of interest.

\section{References}

1. Thammasiri, K. Orchids in Thailand: A Success Story; APAARI, FAO, Angkor Publishers Ltd.: New Delhi, India, 1997.

2. Department of Agricultural Extension. Statistics of Cut-Flowers and Orchid Production; Ministry of Agriculture and Cooperatives: Bangkok, Thailand, 2015.

3. Thammasiri, K. Sustainable management of Thai orchid species. In Proceedings of the 11th Asia Pacific Orchid Conference, Okinawa, Japan, 2-11 February 2013; pp. 92-96.

4. Thammasiri, K. Ex situ conservation of Thai orchid species. In Proceedings of the 20th World Orchid Conference, Sands Expo and Convention Center, Singapore, 13-20 November 2011; pp. 141-148.

5. Dress, R.L. The orchids, Natural History and Classification; Harvard University Press: Cambridge, MA, USA, 1981. 
6. Thaithong, O. Orchids of Thailand; Office of Environmental Policy and Planning: Bangkok, Thailand, 1999; p. 239.

7. Arditti, J.; Ernst, R. Micropropagation of Orchids; John Wiley \& Sons, Inc.: New York, NY, USA, 1993.

8. Thammasiri, K. Current status of orchid production in Thailand. Acta Hortic. 2015, 1078, 25-33. [CrossRef]

(c) 2016 by the author; licensee MDPI, Basel, Switzerland. This article is an open access article distributed under the terms and conditions of the Creative Commons Attribution (CC-BY) license (http://creativecommons.org/licenses/by/4.0/). 